\title{
Znaczenie autorstwa wytworów intelektualnych w szkole w zależności od koncepcji edukacji
}

\section{The Significance of Intellectual Property in School Depending on Education Conceptualization}

\begin{abstract}
Cheating in school, which involves presentation of someone else's work as one's own in order to obtain a reward and avoid punishment by meeting the teacher's expectations, seems to take place in heteronomous education, which is subordinated to a given curriculum. There is no reason for cheating in autonomous education, where the authorship of students and teachers in school is respected. Nevertheless, schools with their students and teachers do not enjoy a full autonomy and they never will. Autonomous education consists in implementing a curriculum derived from the students and teachers' internal interpretation of educational good and giving every student an opportunity to enjoy it. The educational good has the nature of an ideal, which is not directly accessible, but which can be captured by the human mind only through inner interpretation, although never fully and never clearly enough. It is essential to introduce education in relation to the child's development. Following Szuman (1959), Przetacznikowa (1963) and Wygotski (1971) - Niemczyński $(2016 a, 2017)$ presented a theory of the convergence of child's development with education. It argues that the autonomous development of children and adolescents draws support from education as long as education protects it from heteronomous pressure. The more effective this protection is, the less probability there is of cheating in school and the more importance is awarded to the respect for the authorship of intellectual products at school. This could take place in a school managed in a way that respects the autonomy of education.
\end{abstract}

Key words: plagiarism, school education, child development, autonomy.

Słowa kluczowe: plagiat, edukacja, rozwój, autonomia.

\section{WPROWADZENIE}

Współczesna szkoła i nauczyciele mają problem, jak poradzić sobie ze zjawiskiem oszustwa edukacyjnego - przedstawiania przez uczniów prac cudzych jako swoich własnych. Skupiają się na próbach wdrażania zakazów i nakazów z użyciem kar, które mają na celu wzmocnić posłuszeństwo ucznia. Niewiele to jednak wspomaga rozwój moralny uczniów. Przypomina raczej działania policyj- no-śledcze i wygląda na bezradność szkoły i nauczycieli w obszarze edukacji społeczno-moralnej. Takie działania nie wynikają przecież z relacji wzajemnego szacunku z uczniami, która sprzyja rozwojowi autonomicznego umysłu i osobowości ucznia, ceniącego wolny wybór i biorącego za swoje wybory odpowiedzialność oraz respektującego prawa i wolności innych (Piaget, 1966a). Wychowanie oparte na jednostronnym szacunku, wymuszającym bezwzględne posłuszeństwo i uległość ucznia 
względem nauczyciela nakłada na młodego człowieka heteronomiczną dyscyplinę nakazów i zakazów, niesprzyjającą wypracowaniu przez społeczność szkolną własnych norm, zasad i wartości. Wytwór intelektualny ucznia staje się w takich okolicznościach środkiem do osiągnięcia pragmatycznych celów poza edukacyjnych, takich jak unikanie kary, uzyskanie dobrej oceny, aprobaty społecznej, perspektywy na dobrze płatne zatrudnienie w przyszłości itp. Oznacza to ryzyko moralnej degradacji wytworów edukacyjnych ucznia. Przestają bowiem one świadczyć o rzetelnym zaangażowaniu w naukę, a stają się wymienną wartością użytkową. Wciągnięte zostają do transakcji społecznych, w których chodzi o inne wartości. Skupienie się na wykrywaniu plagiatu wytworów edukacyjnych oraz na nakładaniu kar zatrzymuje się na powierzchni życia społecznego i nie dotyka sedna problemu, którego oszustwo edukacyjne jest jednym z przejawów. Tym problemem jest podporządkowanie edukacji innym wartościom w życiu społecznym, naruszające jej status dobra samego w sobie. Oddaje się przez to edukację W zależność od innych wartości (Bauman, 1994; Bourdieu, Passeron, 2006; Niemczyński, 2014).

\section{WYTWORY INTELEKTUALNE UCZNIÓW W SZKOLE}

Szacunek dla autorstwa jest szacunkiem dla osoby jako podmiotu tworzącego dzieło, w które wkłada ona swój wysiłek, zdolności, umiejętności, wiedzę i emocje - samą siebie angażując do określenia zadania, jakie podejmuje i za jego wykonanie bierze odpowiedzialność. Tymczasem w szkole głównie nie tego się oczekuje. Liczy się przede wszystkim na to, że uczniowie wykonają zadania prawidłowo, czyli też w oczekiwany sposób. Stawianie pytań i formułowanie zadań nie należy do uczniów. Tego się nie uczą. W zasadzie nie uczą się również znajdowania, proponowania, sprawdzania i wybierania rozwiązań, ponieważ prawidłowe sposoby rozwiązania oraz prawidłowe odpowiedzi już istnieją w dorobku kulturowym ludzkości i zna je nauczyciel, który ma je uczniom udostępnić, przekazać czy poprowadzić ich do odkrycia takich prawidłowych odpowiedzi i rozwiązań. Wystarczy, żeby uczeń szedł za nauczycielem, a nauczyciel za programem, w nim bowiem zawarty jest obowiązujący przekaz dorobku kulturowego ludzkości. Żadne autorskie wyzwania odpowiedzialności za własne wytwory intelektualne nie są kierowane ani do uczniów, ani do nauczycieli. Niczego istotnego nie mają wymyślać ani tworzyć, co najwyżej mają nauczyciele tylko to wymyślać, jak poprawnie przekazać rzeczy już im znane, a uczniowie, jak je odebrać, opanować, reprodukować i skorzystać z nich do rozwiązania zadań szkolnych, zazwyczaj o niejasnych albo zgoła żadnych powiązaniach $\mathrm{z}$ realnymi problemami i zadaniami bieżących sytuacji $\mathrm{w}$ obecnym świecie społecznym.

Autorski proces tworzenia wiedzy, umiejętności, postaw, wartościowań nie znajduje się w centrum uwagi edukacji w szkole. Liczy się tylko rezultat, który musi być zgodny z rozwiązaniami wziętymi z dorobku kulturowego ludzkości, z zasobów tam się znajdujących i niepodlegających dyskusji. Na rezultatach skupia się ocena ucznia. Niknie autor i proces tworzenia. Pozostaje rezultat i on tylko się liczy w społecznych relacjach w szkole i poza nią. Uczeń niczym sportowiec pragnący wystąpić na igrzyskach musi osiągnąć odgórnie ustalony wynik, minimum olimpijskie. Ostatecznie jednak społecznie liczy się zwycięstwo. Aby nie wypaść z konkurencji, należy się stosować do jej wymogów i można oczekiwać ewentualnie na zindywidualizowane według potrzeb poszczególnych uczniów sposoby przygotowania do zawodów i na trenerskie wspomaganie przygotowania dobrej formy na egzamin. Pomysłowość i autorski charakter aktywności edukacyjnej ucznia i nauczyciela ograniczają się do tego, jak to zrobić, aby utrzymać się w konkurencji zgodnie z obowiązującymi przepisami prawa szkolnego, w tym regulaminami oceny aktywności ucznia. Szkoła i uczniowie z nauczycielami mogą cieszyć się pewną swobodą w tworzeniu tych formalnych regulacji wewnątrzszkolnych, ale w granicach wyznaczonych centralnie dla wszystkich w systemie edukacji. Poza ich odpowiedzialnością, a więc też poza zasięgiem ich działalności edukacyjnej, pozostaje 
tworzenie programu edukacji z jego celami, chociaż zobowiązują się do jego realizacji, podpisując umowę na taką właśnie pracę w szkole. Nienaruszalne są treści programu nauczania, czyli wybrane dzieła cenionych twórców, które mają znaleźć uznanie w umysłach i osobach uczniów i nauczycieli w postaci pragnienia i zdolności ich reprodukcji. Szkoła i edukacja w niej zostają wciągnięte przez takie ich zaprogramowanie do odgrywania roli, w której okazują się niezbędne, lecz niesamodzielne, a nawet podporządkowane siłom społecznym w ich zmaganiach o utrzymanie lub zmianę porządku społecznego. Edukacja zaangażowana do zadań społeczno-politycznych staje się stronnicza i arbitralna, a wreszcie - co najbardziej niepokojące - indoktrynuje młodych, ograniczając ich możliwości cieszenia się życiem wolnych i odpowiedzialnych osób i obywateli (Kohlberg, Mayer, 1993; Niemczyński, 2016a).

Autor reprodukcji nie może liczyć na taki szacunek i podziw, jak twórca oryginalnego dzieła, chociaż i on jest przecież autorem swego wytworu. Prawo Archimedesa reprodukowane nieskończoną ilość razy łatwo staje się niczyje, a mnogie autorstwo indywidualnych reprodukcji nie liczy się, nawet jeśli wymaga za każdym razem wysiłku myśli i przeżyć porównywalnego do oryginalnego osiągnięcia. Liczy się bowiem wierność kopii, jeśli ma być uznana za dobrą reprodukcję. Ocena osiągnięcia intelektualnego w szkole transmisji kulturowej nie bierze pod uwagę aktywności umysłowej i zaangażowania, ogranicza się do wytworu i porównania go z obowiązującym wzorem pod kątem wierności jego odwzorowania. Ocena natomiast sprawowania się ucznia bierze wprawdzie pod uwagę aktywność i zaangażowanie, ale wyłącznie w kontekście podążania za nauczycielem, który ma wiedzieć, kiedy i czym zajmie się uczeń oraz jaką drogą dojdzie do pożądanego przez szkołę rezultatu. Regulacja aktywności umysłowej ucznia i jego zaangażowania przejęte zostają przez instytucję szkoły i państwowego programu edukacji w niej, a standard tej regulacji obowiązuje niezależnie od tego, kto jest jego autorem, ani też kto jest twórcą dzieła podlegającego standaryzacji (Niemczyński, 2011-2015).
Prawo Archimedesa było poznane niezależnie od Archimedesa niezliczoną ilość razy przez nieznających wcześniej tego prawa konstruktorów jednostek pływających, zarówno współczesnych mu, jak i działających przed nim i po nim, z których każdy był autorem swojego rozwiązania problemu przez samego siebie sformułowanego. Obserwacje tego, że jedne ciała toną, a inne utrzymują się i pływają na powierzchni zbiorników wody, mogą się wydarzyć, gdy np. interesuje nas, jak przetransportować ludzi i rzeczy morzem z jednej wyspy na drugą. Nie ma powodu sądzić, że uczniowie dzisiejsi, stając przed tego rodzaju praktycznym zadaniem, nie doszliby do poznania prawa Archimedesa, niekoniecznie od razu ani od początku w tak eleganckim sformułowaniu, jak je przedstawiają zawodowi fizycy, ale przecież wystarczająco dobrym do wywiązania się z zadania, jakie przed sobą postawiliby. A na swojej drodze do wykrycia tego prawa i skorzystania z niego w konstrukcji jednostki pływającej użyliby wielu dostępnych im składników dorobku kulturowego ludzkości, sami wśród nich dokonując wyborów na własną odpowiedzialność. Stąd też byliby autorami własnego rozwiązania, a nie kopistami rozwiązania cudzego.

Nie oczekuje się jednak od nikogo w szkole, ani od uczniów, ani od nauczycieli, niczego, co byłoby ich własnym rozwiązaniem problemu przez nich samych sformułowanego lub wziętego przez nich do rozwiązania. Oczekuje się natomiast tego, żeby rozwiązanie było własną kopią oryginału rozwiązania przychodzącego spoza szkoły, a będącego cudzym rozwiązaniem problemu też w obcym sformułowaniu, a nie własnym. A ponadto obowiązkowo należy się przejąć już sformułowanym problemem i każdym innym gotowym składnikiem programu nauczania, skierowanym po to właśnie do szkoły. A nawet więcej się oczekuje - chociaż już nie tak jawnie bez żenady - mianowicie obligatoryjnego podziwu dla przyrządzonego do obowiązkowej konsumpcji sformułowania problemu i należnego zachwytu dla funkcjonującego rozwiązania. W takim autorytatywnym klimacie społeczno-moralnym niewiele mamy miejsca w każdej konkretnej szkole podległej centralnej regulacji programowej na 
szacunek dla uczniów i nauczycieli jakowolnych i odpowiedzialnych podmiotów własnej edukacji i autorów wytworów edukacyjnych, powstających dla realizacji własnych programów uczenia się w szkole ze wspomaganiem ucznia w pełnym rozwoju jako indywidualnej o s o b y (Łuczyński, 2009, 2011; Niemczyński, 2011-2015).

\section{AUTONOMIA EDUKACJI I JEJ OGRANICZENIAHETERONOMICZNE}

Edukacja jest wartością samą w sobie, czyli wartością autonomiczną, a nie czymś bezwartościowym, co dopiero staje się wartościowe wtedy, gdy czemuś służy. To wcale nie znaczy, że nie może do czegoś posłużyć, że jest bezużyteczna. Podmiotem wartości edukacji jest człowiek, stający się dzięki niej człowiekiem wykształconym i to on posłużyć się może swoim wykształceniem, a także on odpowiada za użytek, jaki zrobi ze swojej edukacji. Może pozostać jej wierny, czyniąc z niej użytek godny człowieka wykształconego, a może też sprzeniewierzyć się jej, gdy uczyni z niej niegodziwy użytek. Może się znaleźć w szkole pod presją heteronomicznych celów stawianych dla realizacji programu przychodzącego spoza szkoły. Potem także w życiu dorosłym czeka go presja społeczna innego rodzaju celów niegodnych wykształconego człowieka. Dla utrzymania się w pozycji człowieka godnego wykształcenia, jakie osiągnął, może polegać przede wszystkim na własnej edukacji, w tym zwłaszcza na sile charakteru, jaką nabył w toku zmagania z wyzwaniami w cyklach wychowania i edukacji, ale też na nabytych tą drogą sprawnościach poznawczych, aksjologicznych, społecznych, interpersonalnych $\mathrm{i}$ umiejętnościach radzenia sobie z samym sobą (Luczyński, 2011; Niemczyński, 2016a). W grę wchodzi nie tylko już ukształtowana postać takiego wieloskładnikowego ogółu kompetencji umysłu, ale także wspomniana siła charakteru, wyrażająca się zdolnością brania na siebie odpowiedzialności, a nie uchylania się przed nią, zdolnością sprosta- nia jej wymogom i wywiązania się z nich, a nie zrzucenia jej z siebie na innych lub na okoliczności, a wreszcie zdolnością przyjęcia wezwania do zdania sprawy z tego, czy i jak podjęło się odpowiedzialność oraz czy i jak się sprostało jej wymogom (Ingarden, 1972; Szuman, 2014).

\section{STOSUNEK WYCHOWANIA I EDUKACJI DO ROZWOJU}

Jeśli nadrzędnym celem edukacji jest wykształcenie uczniów, to trzeba zadać pytanie o związki edukacji z rozwojem psychicznym dzieci i młodzieży. Adam Niemczyński (2014, 2016a, 2017) argumentuje za przyjęciem twierdzenia, że rozwój dzieci i młodzieży przebiega w kierunku pełnego wykształcenia się umysłu i osobowości. Taki ideał rozwoju mógłby się zgadzać z ideałem wychowania i edukacji. Jednakże w literaturze naukowej można wyróżnić kilka stanowisk w tej kwestii (Szuman, 1959; 2014; Wygotski, 1971; Piaget, 1966b, 1977a, 1977b; Niemczyński, 1994, 2000, 2011). Powstaje pytanie, jakie mają znaczenie różnice miedzy nimi $\mathrm{i}$ ich rozmijanie się z twierdzeniem o pokrywaniu się ideału wychowania $\mathrm{z}$ ideałem rozwoju.

\section{Natywizm i dojrzewanie}

Jedno z nich wyraża się w twierdzeniu, że wychowanie i edukacja niczego dobrego nie przyniosą, a nawet mogą zaszkodzić, jeśli będą przedwczesne, ponieważ natrafią na grunt nieprzygotowany jeszcze przez rozwój dziecka. Zarazem nie mogą się spóźnić, gdyż okres rozwoju dziecka, kiedy podatne jest ono na określone oddziaływania wychowawcze i edukacyjne, może minąć. To stanowisko znajdujemy w każdej teorii natywistycznej, czyli przyjmującej tezę o wrodzonej determinacji rozwoju poszczególnych funkcji psychicznych. Każda z nich dochodzi do dojrzałej postaci w odpowiednim do tego czasie i potrzebuje do tego wparcia przez wspomagające środowisko. Wy chowanie i edukacja mają się dostosować do potrzeb rozwoju dziecka w kolejnych okresach, jeśli dojrzewanie wrodzonych funkcji 
psychicznych ma mieć prawidłowy przebieg (Niemczyński, 1994, 2011).

\section{Środowisko i doświadczenie w nim nabywane}

Drugie z głównych stanowisk w sprawie stosunku wychowania do rozwoju przenosi ciężar determinacji rozwoju na środowisko i nabywane w nim doświadczenie. Wrodzona jest jedynie zdolność do uczenia się z doświadczenia i przez to do elastycznego dostosowania aktywności do zmieniających się warunków otoczenia. Dzieci i młodzież uczą się w społecznym świecie z jego normami i regulacjami tego właśnie, w jakich okolicznościach, jakie zachowanie przynosi aprobatę lub dezaprobatę. Praktykowane przez rodziców, wychowawców i nauczycieli nakładanie różnego rodzaju kar i nagród naprowadza dzieci i młodzieży na zachowania zgodne z normami i regulacjami społecznymi. Praktyki wychowawcze i edukacyjne ułożone są według wieku. $Z$ wiekiem zmienia się repertuar zachowania młodych. Te zmiany to rozwój w tym ujęciu. A k ty w n o ść wychowanków i uczniów dostosowuje się z upływem czasu życia do obowiązujących zmian oczekiwań wychowawców i nauczycieli wobec młodych w kolejnych okresach ich życia, które są zarazem kolejnymi okresami wychowania i edukacji (Niemczyński, 1994, 2011).

\section{Niezależność od tego, co wrodzone, i od tego, co nabyte ze środowiska}

Jean Piaget ustanowił trzecie stanowisko w kwestii stosunku wychowania i edukacji do rozwoju umysłowego dzieci i młodzieży, ponieważ przeniósł ciężar determinacji rozwoju do samego rozwoju. Dziedziczność i doświadczenie w środowisku mają tutaj znaczenie czynników jedynie pobudzających lub hamujących dokonywanie się rozwoju. Przebiega on według własnych praw. Nie jest ani dojrzewaniem wrodzonych funkcji psychicznych, ani zależną od wieku życia serią zmian aktywności dla sprostania zmieniającym się z wiekiem oczekiwaniom społecznym. Umysł u Piageta jest adaptacyjną funkcją organizmu. Nazywa on tę funkcję inteligencją, a ma być ona adaptacją w swoistym znaczeniu tego terminu. Nie jest bowiem adaptacją morfologiczno-fizjologiczną, lecz funkcjonalną i posiada własne składniki, wewnętrzny w postaci stabilizującej ją organizacji oraz zewnętrzny w formie asymilacyjno-akomodacyjnej aktywności, napędzającej rozwojowe transformacje. Układają się one w hierarchię niezmiennej sekwencji stadiów. Zasadą transformacji rozwojowych jest u Piageta destabilizacja obecnego stadium przez oddziaływania asymilowane $\mathrm{z}$ otoczenia, do których akomoduje się aktualny modus operandi, zmieniając stopniowo starą na nową zasadę organizacji aktywności adaptacyjnej. Nadbudowuje się ona nad poprzednią dla przywrócenia równowagi z otoczeniem na wyższym poziomie. Wy c ho wanie i edukacja mogą odegrać taką właśnie rolę stymulującą transformacje rozwojowe, jeśli będą źródłem optymalnej nowości dla aktualnego modus operandi. Nie mogą wnieść niczego do przebiegu rozwoju umysłowego człowieka. A d aptacja umysłowa wytwarza swoje struktury i przetwarza je według własnych praw umysłowej ewolucji (Piaget, 1966b, 1977a, 1977b; Niemczyński, 1994, 2011, 2016a).

\section{Kulturowe narzędzia rozwoju}

Lew Wygotski (1971) sformułował czwarte stanowisko w sprawie stosunku wychowania do rozwoju znane jako koncepcja strefy najbliższego rozwoju. Akceptuje on tezę natywizmu o wrodzonych cyklach dojrzewania pierwotnych funkcji psychicznych i twierdzi, że rozwój zostaje w tej strefie przestawiony na inną drogę przez tworzące ją społeczno-kulturowe procesy opiekowania się dziećmi, ich wy chowania i edukacji. Różnią się one od procesów pierwotnych użyciem w interakcjach społecznych znaków i wszelkich kulturowych tworów znaczeniowych. Ich użycie zmienia przebieg pierwotnych procesów przez to, że znaki pośredniczą $\mathrm{w}$ rozpoznaniu i zaspokojeniu 
potrzeb dziecka. Sygnały istniejącej potrzeby wychodzą od dziecka i są odczytywane przez matkę, a sygnały nadchodzącego zaspokojenia potrzeby płyną od strony matki i są odczytywane przez dziecko. Posługiwanie się znaczeniami kulturowych środków komunikacji uwalnia korzystające $\mathrm{z}$ nich osoby od bezpośredniej presji zdarzeń. Pozwala to na kierowanie przebiegiem interakcji przez wchodzące w nią podmioty przez rozmaite formy porozumiewania się odnośnie do znaczenia różnych składników sytuacji dla jej dokonania się. A to utrzymuje więź społeczną i sprzyja realizacji kulturowo określonych celów uczestników interakcji. Opiekuńcze, wychowawcze i edukacyjne interakcje dokonują się najpierw na międzyosobniczej płaszczyźnie, od której zaczyna się u młodych rozwój typowo ludzkich wyższych postaci funkcji psychicznych. Następnie przechodzą one dalsze przekształcenia na płaszczyźnie interioryzacji, na której finalizuje się ich rozwój. Przejście na płaszczyznę interioryzacji zaczyna się od skierowania na własną aktywność regulacji wcześniej kierowanej na aktywność partnera interakcji. Za pomocą słów adresowanych do samego siebie zamiast do innych podmiot może regulować przebieg własnej aktywności. Na tej drodze wszystko, co jest treścią przekazu kulturowego i wchodzi do spontanicznych w rodzinie lub planowanych w szkole programów wychowania i nauczania może się znaleźć na płaszczyźnie interioryzacjiwiedza o świecie, umiejętności działania w nim oraz wartościowania zachodzących w nim stanów rzeczy, a także umiejętności wyznaczania możliwych do zaprowadzenia w nim stanów rzeczy. Weźmy dla ilustracji przykład najprostszy: gdy małe dziecko zaczyna odczytywać znaczenie gestu wskazywania u matki, to widzimy wówczas bez trudu, że dostosowuje ono swoją uwagę i swoje akcje do wskazywanych obiektów i kierunków. Jego pierwotny bezwarunkowy odruch orientacyjny staje się uwagą kierowaną przez matkę. Stopniowo dziecko samo zaczyna używać tego gestu do skierowania uwagi matki na interesujące je obiekty. Gdy użyje gestu wskazywania w celu skierowania własnej uwagi na wybrany przedmiot, sam ten gest może rychło odpaść jako zbędny z całego kompleksu ruchów zwrócenia się do przedmio- tu. Tak kierowana przez dziecko jego własna uwaga staje się typowo ludzką uwagą dowolną. Wszelkie zresztą składniki tego kompleksu sensoryczno-motorycznego, niezbędne w sytuacji międzyosobniczej do zwrócenia uwagi partnera interakcji, mogą stopniowo zaniknąć jako nieprzydatne w sytuacji osobniczej - kierowania własną uwagą. Dalsze uwewnętrznienie uwagi dowolnej dokona się, gdy kierować się ona będzie na własne wyobrażenia i myśli dziecka, a skupienie uwagi na myślach własnych pociąga za sobą charakterystyczną postawę i ułożenie całego ciała, co oddaje tak wspaniale rzeźba Augusta Rodina zatytułowana Myśliciel (Niemczyński, 1988, 2003-2007).

\section{W stronę kulturowego ladu i społecznego porządku}

Jeszcze inaczej przedstawia stosunek edukacji do rozwoju Niemczyński (2016a, 2017). Nawiązuje on do Szumana (1955, 1959, 2014) koncepcji czterech czynników rozwoju, które Przetacznikowa (1973) podzieliła na warunki (dziedziczność i środowisko) oraz wyznaczniki (aktywność własna oraz wychowanie i edukacja). Dziedziczność dostarcza zawiązków rozwoju funkcji umysłu, a środowisko warunków niezbędnych do dokonania się rozwoju. Następuje wszakże ich rozwój w toku aktywności dziecka, kiedy to nabiera ona stopniowo form typowo ludzkich z zawiązków biologicznego dziedzictwa homo sapiens. A dzieje się to za sprawą oddziaływań wychowawczych i edukacyjnych w świecie społeczno-kulturowym z jego cywilizacyjnymi przemianami historycznymi. Wyraźna różnica, jaka dzieli to stanowisko od teorii Wygotskiego, to klarowne wskazanie na swoiście gatunkowe dla homo sapiens zadatki dziedziczne rozwoju, które mają naturę zawiązków aktywności dla wykszta1cenia się z nich umysłowych funkcji dziecka w typowo ludzkich postaciach, jakie wyznacza wychowanie oraz edukacja, czerpiąc z zasobów kulturowych społeczności. Wychowanie i edukacja nie są przy tym wcale zewnętrznym importem - jak u Wygotskiego - kulturowych przekształceń, ponieważ kulturowa natura aktywności dziecka jest tej aktywności 
dziedzicznym znamieniem. Człowiek rozwija się $\mathrm{w}$ indywidualnym swoim życiu w swoiście ludzki sposób nie tylko i nie tyle dlatego, że przechodzi na inny niż pozostałe gatunki istot żywych szlak rozwoju indywidualnych przedstawicieli gatunku. Szlak tego rozwoju jest rzeczywiście inny niż u wszelkich innych gatunków zoologicznych. Ale nie zaczyna się - jak u Wygotskiego - w okresach dojrzewania poszczególnych funkcji, lecz jest swoisty od początku do końca indywidualnego cyklu życia przedstawicieli gatunku homo sapiens.

Do tego stanowiska teoretycznego, jakie zajął Szuman $(1955,1959,2014)$ i Przetacznikowa (1973), dodaje swoje prace Niemczyński (1988, 1994, 2007, 2016a, 2017) z naciskiem na autonomię indywidualnego rozwoju człowieka oraz na zbieżność konstytutywnego dobra edukacji z ideałem pełnego rozwoju uczniów i wychowanków jako indywidualnych osób. Wskazanie na autonomię indywidualnego rozwoju człowieka (Niemczyński, 1994) zostało rozciągnięte na relacje społeczne wychowania i rozwoju.

Niemczyński (2000) przywołał do psychologicznych badań nad rozwojem umysłu człowieka przypomniane przez Jima Macnamarę (1990) umysłowe operacje idealizacji oraz ideały, czyli obiekty tych operacji. Ideały niejasne w szczególności znalazły zastosowanie w teorii i badaniach nad indywidualnym rozwojem człowieka (Niemczyński, 2007). Wzięta tutaj dla przykładu relacja macierzyństwa jest jedną z mnogości relacji interpersonalnych, w jakich ludzkie życie się toczy od przyjścia na ten świat do odejścia z niego. Każda wypełniona jest swoistą treścią moralną, pochodzącą z interpretacji jej ideału i może zostać wcielona w życie indywidualnych osób. Zmienia się z biegiem lat realizacja takich ról, z których składa się życie ludzkie. Ze zmianami interpretacji ideałów ról wiążą się przeobrażenia sposobów angażowania się w nie, a to rzutuje na konkretne zachowania wcielające ideały w życie. Ludzki charakter życia bierze się z tej właśnie obecności w nim nieklarownych i bezpośrednio niedostępnych ideałów różnego rodzaju relacji społecznych. Jest to obecność za pośrednictwem interpretacji i zawsze jedynie cząstkowa. W taki pośredni i cząstkowy, chociaż poszerzający się i pogłębiający sposób dostęp do ideałów może posłużyć podmiotowi do regulacji przebiegu wcielenia ich w jego życie w kolejnych fazach rozwoju (Niemczyński, 2007).

Warto zauważyć, że wcielenie ideałów nieklarownych w życie ludzkie dokonuje się nie tylko w jego indywidualnych przebiegach, ale także z natury rzeczy w historycznej przestrzeni społeczno-kulturowej. Są to przecież ideały ról społecznych odnoszące się do relacji społecznych, które są wzajemnie się dopełniające i wzajemnie zwrotne. Matka-dziecko, lekarzpacjent, mąż-żona, nauczyciel-uczeń to tylko kilka z mnogości możliwych do przywołania przykładów. W instytucjach i zasobach kulturowych każdego społeczeństwa znajdują się wprowadzone tam do bieżącej regulacji i do przekazu kolejnym pokoleniom interpretacje ideałów ról społecznych w postaci normatywnej, a więc w formie standardów interpretacji mających moc obowiązywania w każdej ze wszystkich przyjętych przez podmiot na siebie ról i obowiązujących każdego ze wszystkich podmiotów, którzy daną rolę wybrali dla siebie. Są to zarówno regulacje prawne, jak i religijne, obyczajowe, zwyczajowe, obowiązujące ogół społeczności lub niektóre tylko grupy. Znajdują się wśród nich regulacje przyjęte formalnie lub obowiązujące nieformalnie, spisane lub niepisane, ale akceptowane przez społeczność, takie jak kodeksy honorowe, etyczne, moralne, czy inaczej, obowiązujące normy postępowania. Wszystkie te rodzaje norm podlegają zmianom w czasie historycznym, a stałą moc obowiązującą w każdym społeczno-kulturowym tu i teraz mają jako konkretne postacie interpretacji ideałów współżycia ludzi ze sobą. Wychowanie i edukacja są wprowadzeniem młodych w tę aktualną postać historycznego ładu i porządku społeczno-kulturowego, która jest zarazem środowiskiem rozwoju umysłu i osobowości człowieka w pełnym cyklu życia jednostkowego (Niemczyński, 2016a, 2017).

\section{HIPOTEZY DO SPRAWDZENIA W BADANIU EMPIRYCZNYM}

Na początku przeglądu stanowisk w sprawie stosunku wychowania i edukacji do rozwoju znalazła się sugestia, że pełne wykształcenie 
umysłu i osobowości można uznać za określenie zbieżności obu procesów, które bynajmniej nie pokrywają się, lecz niewątpliwie są zarówno niezbędne dla siebie nawzajem, jak i wiążą się ze sobą w różne składające się z nich konstelacje. Społeczność wytwarza ład i porządek normatywny, a edukacja i wychowanie kształtują młodych do życia pod jego regulacją. A to oznacza wybór wartości, jakie zostają nałożone na społeczność mocą systemu władzy przez legislację, egzekutywę administracyjną i sądową kontrolę przestrzegania praw ustanowionych. Wychowanie i edukacja też temu podlegają i powstaje pytanie, czy skazane są na utratę swojej autonomii przez podporządkowanie wartościom panującego ładu i porządku społecznego. Nie wydaje się, aby tak było, z pewnością natomiast są narażone permanentnie na ograniczenia $\mathrm{z}$ tej strony, chociaż natura tych ograniczeń może się zmieniać pod wieloma względami.

Dobrze byłoby też wiedzieć, dlaczego właściwie heteronomiczna ingerencja w wychowanie i edukację jest tak mocna i rozpowszechniona współcześnie. To, że władza publiczna może ją skutecznie realizować, nie wyjaśnia wyboru celów tej ingerencji. Dopiero cele sprawujących władzę przedstawicieli społeczeństwa co utrzymać, a co zmienić w panującym ładzie kulturowym i społecznym porządku - przenoszą się na heteronomiczną ingerencję w program uczenia się w szkole. Jego istota polega na narzuceniu szkole, nauczycielom i uczniom wyboru z materii transmisji kulturowej, co jeszcze samo w sobie nie pozbawia ich szans na wybicie się na niepodległość w codziennej działalności edukacyjnej. Mogą się cieszyć wolnością i samodzielnością do pewnego stopnia mimo oddania cesarzowi co cesarskie. Ważniejsze jest to, że ten narzucony wybór materiału nauczania przynosi również mające obowiązywać wartościowanie i to nie tylko w humanistycznych i społecznych przedmiotach nauczania, ale także w treściach przedmiotów ścisłych i przyrodniczych. Wybór treści, problemów i rozwiązań nie dokonuje się w szkole, w nauczaniu nauczycieli i uczeniu się uczniów. Poza szkołą decyduje się to, co i jak wybierać z treści dorobku kulturowego pod kątem bieżących problemów, jak formu- łować aktualne problemy w różnych dziedzinach życia ludzi, jak poszukiwać rozstrzygnięć, jak wybierać rozwiązania $\mathrm{z}$ wielu nasuwających się, jak oceniać użyte rozwiązania. Autorytet ekspertów, a ostatecznie wola władzy publicznej, o tym wszystkim przesądza i oczekuje podporządkowania się uczniów, nauczycieli i szkół, a nie daje szans na branie odpowiedzialności przez nich za własną edukację w tych zupełnie podstawowych zakresach.

W takim społeczno-moralnym klimacie podporządkowania szkoły woli władzy publicznej i autorytetom z różnych dziedzin życia społecznego mają wytwory intelektualne uczniów przede wszystkim wartość uży tkow ą dla przeżycia z sukcesem przez lata szkolnej edukacji i zakończenia jej z uznaniem na przyjętej przez władzę publiczną skali ocen. Uczniowie i nauczyciele są na drugim planie, żeby nie powiedzieć, że są potrzebni jednie jako „surowy materiał”, a drudzy do „obrobienia tego materiału" wedle dostarczonych wzorów, co i jak powinien opanować uczeń z istniejących zasobów wiedzy, umiejętności, postaw i wartościowania w świecie wspólnego życia ludzi. Bierze się pod uwagę w przypadku każdego ucznia to, czy dany wytwór intelektualny zgadza się z przekazem nauczyciela z programu nauczania i tylko to się liczy. Wytwory są zatem wymienne, co najwyżej różnią się stopniem doskonałości pokrywania się z programowym wzorcem, na podstawie którego nauczyciel je ocenia. Do tych wytworów intelektualnych o wymiennej wartości autorzy mają prawo i mogą nimi rozporządzać, oddając je do oceny nauczycielom $z$ uwzględnieniem norm systemu edukacji, a także mogą przekazać kolegom w zamian za ocenę w ramach stosunków koleżeńskich, niekoniecznie zgodnych z porządkiem systemu edukacji. Tym chętniej mogą to zrobić, im mniej nauczyciele i szkoła poświęcają uwagi i zainteresowania zmaganiom się uczniów z zadaniami, jakie otrzymują do rozwiązania. Wreszcie nie bez znaczenia jest wątła podstawa do przeżywania uznania i szacunku dla samego siebie jako autora biorącego na siebie odpowiedzialność za własne wytwory intelektualne w szkole transmisji kulturowej. 
Celem badania empirycznego będzie wobec tego sprawdzenie, (1) czy rzeczywiście wśród nauczycieli przeważa heteronomiczna interpretacja wartości edukacji w życiu ludzi nad pojmowaniem jej jako dobra autonomicznego; (2) czy istotnie autorstwo wytworów intelektualnych w szkole podlega spragmatyzowaniu, a etyczna wartość autorstwa tych wytworów schodzi na dalszy plan wśród nauczycieli oraz (3) czy zachodzi taki związek, że heteronomia wartości edukacji idzie w parze ze spragmatyzowaniem autorstwa, a autonomia wartości edukacji z etycznym podejściem u nauczycieli do autorstwa wytworów edukacyjnych.

\section{PLAN I METODA BADANIA EMPIRYCZNEGO}

Materiał empiryczny zebrano z badania nauczycieli za pomocą Wywiadu o Dylematach Edukacyjnych (WDE) i poddano analizie według standardowej procedury w celu uzyskania danych o wchodzących $\mathrm{w}$ grę zmiennych - o wartościowaniu edukacji i o autorstwie wytworów edukacyjnych.

\section{Osoby badane i przebieg badania}

W badaniu uczestniczyli nauczyciele szkół podstawowych, gimnazjalnych i licealnych w województwach małopolskim i śląskim w latach 2012-2014 na terenie macierzystych placówek edukacyjnych, gdzie otrzymywali wydrukowane kartki z instrukcją, opisem dwóch sytuacji szkolnych i pytaniami dotyczącymi dylematu w przedstawionych sytuacjach. Autor niniejszego artykułu był osobą badającą we wszystkich przypadkach i odczytywał osobom badanym instrukcje oraz opisy sytuacji dylematu wraz z treścią pytań w czasie, gdy osoby badane śledziły te treści w cichym czytaniu. Następnie upewniał się, czy osoby badane poprawnie rozumieją zadanie, prosząc o zadawanie ewentualnych pytań, na które starał się udzielić odpowiedzi i uzyskać potwierdzenie usatysfakcjonowania nimi. Nauczyciele byli proszeni o udzielenie odpowiedzi w obecności badającego albo w dogodnym dla nich czasie i pozostawienie ich do odbioru przez niego. Rozwiązywali zadanie anonimowo, podając tylko dane o płci i wieku dla zrównoważenia proporcji $\mathrm{w}$ badanych podgrupach pod tymi względami. Zebrano materiał od stu kilkudziesięciu nauczycieli, a do analizy wzięto 90 protokołów po $30 \mathrm{z}$ każdego typu szkół - podstawowej, gimnazjalnej i licealnej. Protokoły wybrano do analizy pod kątem kompletności odpowiedzi na wszystkie pytania oraz jasnego i wyraźnego przedstawienia własnych myśli przez osobę badaną.

\section{Instrument badania: Wywiad o Dylematach Edukacyjnych (WDE)}

W badaniu empirycznym zastosowano narzędzie badawcze autorstwa Adama Niemczyńskiego (2003-2007) o nazwie Wywiad o Dylematach Edukacyjnych (WDE). Przeznaczone jest ono do badania myślenia zaangażowanego w rozpoznanie i uzasadnienie wartości edukacji w życiu ludzi. WDE powstał w nurcie badań poznawczo-rozwojowych zapoczątkowanych przez Piageta (1966b) nad rozwojem pojęć i operacji umysłowych u dzieci i młodzieży. Piaget nazywał swoją metodę badania wywiadem klinicznym, w którym chodzi o poznanie własnego oryginalnego punktu widzenia chorego, czasami bardzo różniącego się od pojęć lekarza. W konsekwencji narzucenia na to, co mówi pacjent, lekarz może zniekształcić, a nie uchwycić w oryginalnej postaci myślenie chorego. Podobnie jak w zadawaniu przez Piageta pytań dzieciom, tak samo w przedstawianym badaniu stawiamy pytania dorosłym i skupiamy się na wychwycenie tego, co może być różnie rozumiane, prosimy o dodatkowe wyjaśnienia za pomocą tzw. pytań sondujących, które mają pobudzić badanego do wyrażenia swoich myśli, ale zarazem niczego mu nie sugerować samym sformułowaniem zdania. Pytanie ,dlaczego?” spełnia taka funkcję, pobudzając do wyjaśnień, ale też parafrazy tego pytania służą temu celowi, np.: „Dlaczego tak myślisz?”, „Dlaczego to jest ważne?”, ,Jakie to ma znaczenie?”, „Czy coś więcej możesz mi o tym powiedzieć?". Dokładnie tak samo należy postępować w czasie badania osób dorosłych, których punkt 
widzenia i podejście do dylematów mogą być inne niż osoby badającej.

Badanie za pomocą WDE zastosowano w wersji pisemnej bez możliwości dalszego sondowania poza wyjściowym pytaniem ,dlaczego?". Wówczas należy się liczyć z otrzymaniem odpowiedzi mało rozwiniętych i wobec tego niejednoznacznych bez możliwości dalszego ich sondowania. $Z$ tej racji o wiele obszerniejszy materiał zebrać trzeba tym sposobem, licząc się z odrzuceniem znacznej części zebranych protokołów. W przedstawianym badaniu w celu uzyskania 90 protokołów nadających się do analizy wykonano 124 badania wywiadem WDE.

Wywiad o Dylematach Edukacyjnych może w różnych badaniach mieć różne opowiadania z dylematami szkolnej edukacji i wówczas też pytania mają treść inną, a stosowną do treści dylematów w danej wersji. Także liczba opowiadań użytych do badania tych samych osób może być różna, lecz nie mniejsza niż dwa opowiadania, ponieważ niezbędne jest stwierdzenie, czy każda z osób badanych wyraziła swoje podejście do dylematów, czyli sobie właściwą perspektywę, w jakiej ujmuje wartość edukacji i powiązanych z nią wartości, podejmując decyzję o tym, co powinno być $\mathrm{w}$ przedstawionych sytuacjach zrobione, i uzasadniając, dlaczego tak właśnie powinno się postępować. A oto użyta wersja w przedstawianym badaniu:

Wydział Zarządzania i Komunikacji Społecznej Uniwersytetu Jagiellońskiego prowadzi badania nad ściąganiem, odpisywaniem, przywłaszczaniem sobie cudzych opracowań przez uczniów w szkole. Interesuje nas szersze tło i źródła takiego zachowania. Chciałbym wobec tego prosić $\mathrm{Pa}-$ nią/Pana o odpowiedź na kilka pytań. Zależy mi na poznaniu Pani/Pana zdania o tych sprawach, ale również zależy mi bardzo na poznaniu uzasadnienia, dlaczego Pani/Pan tak właśnie o tych sprawach myśli i tak je ocenia. Dlatego proszę o szczególne zwrócenie uwagi na rozwinięcie swoich myśli, bo taki jest sens pytań „dlaczego?” poniżej postawionych.

I. Zdarza się uczniom w szkole odpisywać od kolegi lub ściągać z innych źródeł coś, co podają jako zadanie wykonane przez siebie samego.
Zdarza się to w wielu przypadkach sporadycznie. Uczeń dopuszczający się takiego kroku nie robi tego systematycznie i nie jest to jego ustalony sposób funkcjonowania w szkole.

1. Co w takich przypadkach powinien zrobić nauczyciel, dowiadując się o tym?

2. Dlaczego tak właśnie byłoby najlepiej uczynić?

3. Co w takich przypadkach powinni zrobić rodzice ucznia, dowiadując się o tym?

4. Dlaczego takie postępowanie byłoby właściwe?

5. Co powinien zrobić uczeń dopuszczający się takiego postępku?

6. Dlaczego tak właśnie powinien zrobić?

II. Istnieją również takie przypadki w szkole, że niektórzy uczniowie przyjmują ściąganie, odpisywanie, przywłaszczanie cudzych prac jako systematyczny sposób uzyskiwania pozytywnych ocen w szkole.

Pyt. 1-6 jak wyżej.

\section{Analiza materiału z badania WDE}

Celem analizy odpowiedzi każdej osoby badanej na serię pytań dotyczącą pierwszej oraz drugiej sytuacji było zakwalifikowanie ich do jednej z dwóch kategorii każdej z obu zmiennych tak, że każda osoba badana uzyskała ostatecznie ogólne dwa wyniki - jeden to kwalifikacja do autonomii lub heteronomii, a drugi do etycznego lub spragmatyzowanego autorstwa. Obie serie pytań składają się z trzech par pytań, a w każdej $\mathrm{z}$ nich mamy pytanie główne o to, co powinno być zrobione, a drugie o uzasadnienie, dlaczego to właśnie ma być zrobione. Odpowiedzi na oba pytania każdej pary stanowią jednostkę analizy materiału według kryterium całostki myślowej w rozumieniu Romana Ingardena (1976), czyli jednej zrozumiałej myśli o czymś bez wychodzenia poza nią samą, niezależnie od tego rzecz jasna - że może się ona łączyć z innymi myślami w tej samej sprawie. Posłużono się takim podziałem na jednostki materiału, aby uczynić możliwe porównania między sędziami niezależnymi w celu oceny rzetelności analizy na elementarnym poziomie, ale wciąż odnoszącym się do sensu argumentacji osób badanych za wybranym rozwiązaniem dylematu. Przyjęto również zasadę korzystania z jednej i tej samej 
całostki tylko jeden raz. Wykluczone zostało tym sposobem korzystanie z jednej i tej samej porcji materiału do kwalifikacji myślenia osoby badanej do jednej i do drugiej zmiennej. Niemczyński (2003-2007) opracował schemat analizy materiału $\mathrm{z}$ badania WDE do zastosowania w każdej wersji badania niezależnie od treści dylematów i pytań. Składa się on z czterech kroków.

Krok 1: Identyfikacja całostek myślowych. W przypadku każdej osoby badanej mamy zazwyczaj 6 całostek myślowych. Znaczenie odpowiedzi na każde kolejne dwa pytania można bowiem przedstawić jako jedną myśl o powinności wobec młodego sprawcy, jaka ma być powinnością - w kolejnych całostkach - nauczyciela, rodziców, a w końcu samego młodocianego. Na przykład w odpowiedziach nauczycielki gimnazjum w wieku 36 lat mamy następujące całostki myślowe: a) „Nauczyciel powinien mu uświadomić, że w ten sposób niczego nie osiągnie w nauce, żadnej wiedzy się nie zdobędzie”; b) „Rodzice powinni dopilnować, aby dzieci uczyły się systematycznie, ponieważ wówczas będą miały większą wiedzę”; c) „Uczeń powinien przyznać się do ściągania, aby być uczciwym wobec innych"; d) „Nauczyciel powinien postawić ocenę niezadowalającą, ponieważ to sprawi, że uczeń się nauczy, a to byłoby najuczciwsze”; (e) „Rodzice powinni porozmawiać z nim, żeby zrozumiał, ponieważ to jest lepsze niż przemoc”; f) „Uczeń powinien przyznać się do popełnienia błędu, godnie przyjąć ocenę niedostateczną, nauczyć się i poprawić ocenę".

Krok 2: Klasyfikacja całostek myślowych. Każdą rozpoznaną całostkę myślową klasyfikuje się do określonej kategorii danej zmiennej za pomocą jednego z trzech wskaźników (zob. Tabela 1). Każdy wskaźnik ma dwa warianty, z których jeden wskazuje na jedną, a drugi na drugą kategorię wybranej zmiennej. Kategorie wartości edukacji to autonomia i heteronomia, a każda $\mathrm{z}$ nich rozpoznawana jest w materiale $\mathrm{z}$ badania przez jeden wskaźnik z pary mającej zastosowanie w odniesieniu do danej całostki myślowej. To samo odnosi się do wartości drugiej zmiennej, gdzie każda para wskaźników ma zastosowanie do wskazania na ujęcie au- torstwa wytworu jako wartości etycznej albo pragmatycznej w wybranej całostce myślowej. Wskaźniki odnoszą się do różnych aspektów argumentacji za wartością edukacji oraz za rozumieniem znaczenia autorstwa wytworów edukacyjnych. Przedstawione w części teoretycznej konceptualizacje obu zmiennych pozwoliły określić wymienione w Tabeli 1 wskaźniki operacyjne do zastosowania w klasyfikacjach całostek myślowych. Niech za przykład posłuży klasyfikacja całostek myślowych podanych powyżej z badania nauczycielki gimnazjum.

a) „Nauczyciel powinien mu uświadomić, że w ten sposób niczego nie osiągnie w nauce, żadnej wiedzy się nie zdobędzie". Ma tutaj zastosowanie wskaźnik W1 kwalifikujący tę całostkę myślową do pierwszej kategorii K1 rozumienia wartości edukacji Z1, ponieważ osoba badana przywiązuje tutaj wagę do rozgraniczenia pozoru od autentycznej wartości edukacyjnej wytworów intelektualnych ucznia dla jego edukacji. Odpisywanie daje pozór wiedzy, który może być użyteczny, ale nie ma wartości dla wykształcenia, gdyż to trzeba osiągnąć wysiłkiem własnym, autonomicznym.

b) „Rodzice powinni dopilnować, aby dzieci uczyły się systematycznie, ponieważ wówczas będą miały większą wiedzę". Ma tutaj zastosowanie wskaźnik W1 kwalifikujący do pierwszej kategorii K1 rozumienia wartości edukacji Z1, ponieważ wiedzę (wykształcenie) uzyskują dzieci, gdy się uczą, a większy jej przyrost następuje dzięki systematycznej pracy. Wiedza (wykształcenie) ma wartość samą w sobie, nabywa się ją dla niej samej, dla jej posiadania.

c) „Uczeń powinien przyznać się do ściągania, aby być uczciwym wobec innych". Ma tutaj zastosowanie wskaźnik W3 kwalifikujący do pierwszej kategorii K1 etycznego rozumienia wartości wytworów intelektualnych w szkole Z2, ponieważ w grę wchodzi status suwerena $\mathrm{w}$ rozporządzaniu własnym wytworem intelektualnym w szkole. Jeśli nieuczciwie wobec innych, to trzeba to przyznać wobec nich.

d) „Nauczyciel powinien postawić ocenę niezadowalającą, ponieważ to sprawi, że 
uczeń się nauczy, a to byłoby najuczciwsze". Ma tutaj zastosowanie wskaźnik W2 kwalifikujący do pierwszej kategorii K1 etycznego rozumienia wartości wytworów intelektualnych w szkole Z2, ponieważ danie uczniowi oceny niezadowalającej jest działaniem na rzecz wykazania się przez niego uczciwie zdolnością uczenia się i nauczenia się $\mathrm{w}$ rezultacie własnego wysiłku i starania.

e) „Rodzice powinni porozmawiać z nim, żeby zrozumiał błąd, ponieważ to jest lepsze w wychowaniu niż przemoc". Ma tutaj zastosowanie wskaźnik W3 kwalifikujący do pierwszej kategorii K1 rozumienia wartości edukacji Z1, ponieważ w grę wchodzi nabycie kompetencji radzenia sobie $\mathrm{z}$ samym sobą drogą, która do tego prowadzi, a nie inną, nieadekwatną.

f) „Uczeń powinien przyznać, że popełnił błąd, przyjąć godnie ocenę niedostateczną, nauczyć się i poprawić ocenę". Ma tutaj zastosowanie wskaźnik W3 kwalifikujący do kategorii K1 etycznego rozumienia wartości wytworów intelektualnych w szkole Z2, ponieważ wchodzi tu $\mathrm{w}$ grę wzięcie i odpowiedzialności za własne postępowanie przez ucznia w tej sytuacji społecznej i poniesienie konsekwencji.
Krok 3. Kwalifikacja protokołu w aspekcie jednej i drugiej zmiennej. Obie zmienne mają charakter dwubiegunowy, co oznacza istnienie kontinuum pomiędzy nimi, na którym kategorie przeciwstawne mają swoją reprezentację w każdym punkcie, lecz z różną intensywnością. $\mathrm{Na}$ przykład im bliżej bieguna autonomii, tym mniej heteronomii, aż po zerową jej wartość na samym biegunie autonomii. Punkt środkowy dymensji dwubiegunowej reprezentuje równoważność autonomii i heteronomii $\mathrm{w}$ myśleniu o wartości np. edukacji. Ten punkt i jego okolice reprezentują niestabilne stany rzeczy w myśleniu według wartości i w rzeczywistości są spotykane wtedy, kiedy dokonuje się zmiana położenia na danej dymensji, czy to w jedną, czy też $\mathrm{w}$ drugą stronę. $\mathrm{W}$ praktyce analizy protokołu $\mathrm{z}$ badania oznacza to, że $\mathrm{w}$ toku argumentacji osoby badanej za preskrypcjami, jakie uzasadnia, można w wielu wypadkach dostrzegać oznaki np. zarówno autonomii, jak i heteronomii, lecz zwykle jedno ujęcie wartości będzie się mniej lub bardziej jasno i wyraźnie wybijać na pierwszy plan. I to przesądza o kwalifikacji całostki myślowej. Przy tej okazji warto przypomnieć o selekcji materiału pozostawiającej poza analizą protokoły, w których nic wystarczająco jasno i wyraźnie nie uzasadnia żadnej kwalifikacji materiału z badania.

Tabela 1. Zmienne, ich kategorie oraz wskaźniki kategorii

\begin{tabular}{|l|l|}
\hline \multicolumn{2}{|c|}{ Pierwsza zmienna (Z1): wartość edukacji } \\
\hline \multicolumn{1}{|c|}{ I kategoria (K1): autonomiczna } & \multicolumn{1}{|c|}{ II kategoria (K2): heteronomiczna } \\
\hline $\begin{array}{l}\text { Pierwszy wskaźnik (W1): edukacja jest wartością } \\
\text { samą w sobie i nie wymaga uzasadnienia przez } \\
\text { inne, zewnętrzne cele, jakim może służyć. }\end{array}$ & $\begin{array}{l}\text { Pierwszy wskaźnik (W1): edukacja jest wartoś- } \\
\text { ciowa o tyle, o ile służy osiągnięciu innych, ze- } \\
\text { wnętrznych wobec niej celów. }\end{array}$ \\
\hline $\begin{array}{l}\text { Drugi wskaźnik (W2): głównym celem edukacji } \\
\text { jest pełny i autonomiczny rozwój człowieka jako } \\
\text { indywidualnej osoby. }\end{array}$ & $\begin{array}{l}\text { Drugi wskaźnik (W2): głównym celem edukacji } \\
\text { jest transmisja z góry określonej wiedzy, umiejęt- } \\
\text { ności i postaw. }\end{array}$ \\
\hline $\begin{array}{l}\text { Trzeci wskaźnik (W3): nauczyciel wspoma- } \\
\text { ga uczniów w stawiania sobie celów w rozwoju } \\
\text { kompetencji poznawczych, aksjologicznych, spo- } \\
\text { łecznych, interpersonalnych oraz radzenia sobie } \\
\text { z samym sobą. }\end{array}$ & $\begin{array}{l}\text { Trzeci wskaźnik (W3): zadaniem nauczyciela jest } \\
\text { przekaz wiedzy, umiejętności i postaw oraz ocena } \\
\text { stopnia ich przyswojenia przez ucznia. }\end{array}$ \\
\hline
\end{tabular}


Tabela 1. cd.

\begin{tabular}{|l|l|}
\hline \multicolumn{2}{|c|}{ Druga zmienna (Z2): autorstwo wytworów intelektualnych w szkolne } \\
\hline \multicolumn{1}{|c|}{ I kategoria (K1): wartość etyczna } & \multicolumn{1}{|c|}{ II kategoria (K2): wartość pragmatyczna } \\
\hline $\begin{array}{l}\text { Pierwszy wskaźnik (W1): autorstwo rodzi odpo- } \\
\text { wiedzialność osoby za wytwory jej aktywności } \\
\text { intelektualnej. }\end{array}$ & $\begin{array}{l}\text { Pierwszy wskaźnik (W1): autorstwo daje tytuł } \\
\text { do uznania prawa autora do własności jego wy- } \\
\text { tworów intelektualnych. }\end{array}$ \\
\hline $\begin{array}{l}\text { Drugi wskaźnik (W2): wytwory są świadectwem } \\
\text { zdolności autora do rozwoju własnej aktywności } \\
\text { intelektualnej. }\end{array}$ & $\begin{array}{l}\text { Drugi wskaźnik (W2): użytek z praw autorskich } \\
\text { podlega regulacji według obowiązujących norm } \\
\text { w społeczeństwie. }\end{array}$ \\
\hline $\begin{array}{l}\text { Trzeci wskaźnik (W3): autor ma w społeczeństwie } \\
\text { status suwerena własnej aktywności intelektualnej. }\end{array}$ & $\begin{array}{l}\text { Trzeci wskaźnik (W3): przekazanie do użytku } \\
\text { społecznego zgodą autora wytworu ma aktualny } \\
\text { porządek normatywny. }\end{array}$ \\
\hline
\end{tabular}

Aby zakwalifikować protokół w aspekcie jednej i drugiej zmiennej, należy najpierw zrobić to osobno w odniesieniu do pierwszej i drugiej sytuacji, a dopiero potem ustalić wynik dla całego protokołu $\mathrm{z}$ badania danej osoby. W naszym przykładzie mamy w odniesieniu do dymensji autonomii i heteronomii dwa przypadki całostek myślowych (i) oraz (ii) zakwalifikowane do autonomii i żadnej do heteronomii. Na drugiej dymensji występuje jeden przypadek całostki myślowej (iii) kwalifikujący się do etycznego ujęcia autorstwa i nie pojawia się żaden do pragmatycznego potraktowania autorstwa. Całość trzech całostek $\mathrm{z}$ badania pierwszym dylematem daje zatem wynik $2 \mathrm{x}$ autonomia $\mathrm{i} 1 \mathrm{x}$ etyczne ujęcie. $Z$ badania drugim dylematem mamy w wypadku dwóch całostek myślowych (iv) i (vi) kwalifikacje do etycznego rozumienia autorstwa, a w jednym przypadku (v) do autonomii na dymensji wartości edukacji. W odniesieniu do obu sytuacji pojawia się zatem klarowny wynik na jednej i drugiej dymensji z badania tej osoby, która uzyskuje następujący rezultat: $1 \mathrm{x}$ autonomia edukacji i 1 x etyczne ujęcie autorstwa.

Krok 4. Utworzenie zbioru danych dla ogółu osób badanych. Uzyskane dane z analizy jakościowej w pierwszych trzech krokach zebrać można razem i przeprowadzić ilościowe analizy częstości występowania kategorii obu zmiennych zarówno w całej grupie badanych nauczycieli, jak i w podgrupach, czy to na poziomie całego protokołu, czy też na poziomie dylematów, a także częstości, z jaką znalazły zastosowanie pary wskaźników. Ilościowe analizy mają zastosowanie do określenia trafności i rzetelności danych, a następnie do sprawdzenia hipotez (Dudek, 2015).

\section{Rzetelność danych $\mathrm{z}$ analizy materiału empirycznego}

Posłużono się metodą porównań między sędziami niezależnymi. Autor WDE i autor niniejszego artykułu wykonali niezależne analizy losowo wybranych protokołów z badania 30 osób. Okazało się, że zgodność na poziomie zastosowania wskaźników do kwalifikacji jednostek myślowych wynosiła 67\% (121 przypadków na 180) dla pierwszej i 60\% (108 przypadków na 180) dla drugiej zmiennej. Zgodność na poziomie dylematu zaliczenia do kategorii pierwszej zmiennej uzyskała wartość $80 \%$ (48 przypadków na 60 ), a do kategorii drugiej zmiennej - 75\% (45 przypadków na 60). Zgodność między sędziami na poziomie całego protokołu wynosiła natomiast $90 \%$ (27 przypadków na 30) dla pierwszej zmiennej oraz $80 \%$ (24 przypadki na 30) dla drugiej. Rezultaty porównań są całkowicie zadowalające dla tego rodzaju materiału badawczego i w ich świetle można uznać dane z badania empirycz- 
nego za rzetelne w wystarczającym stopniu, aby można było na nich polegać w sprawdzeniu hipotez (Dudek, 2015).

\section{SPRAWDZENIE HIPOTEZ}

Pierwsza hipoteza to twierdzenie, że wśród nauczycieli przeważa heteronomiczne wartościowanie edukacji nad uznaniem jej wartości autonomicznej. W Tabeli 2 można zauważyć, iż na 90 obserwacji ogółem odnotowano 16 przypadków autonomii, a w 74 wypadkach rozpoznano heteronomię. Zdecydowana większość nauczycieli stanowiąca 83\% wszystkich uczestniczących w badaniu argumentuje za instrumentalną wartością edukacji, a jedynie 17\% nauczycieli uzasadnia wartość edukacji autonomicznie jako dobro samo w sobie. Oznacza to, że pełny rozwój każdego ucznia jako indywidualnej osoby nie jest celem konstytutywnym edukacji dla znacznej części badanych nauczycieli, a jest nim opanowanie takiej wiedzy i umiejętności oraz nabycie takich cech społeczno-moralnego charakteru, jakie są potrzebne do utrzymania obecnego ładu kulturowego i porządku społecznego. Wprawdzie jest to mniejszość, gdyż tylko $17 \%$ uczestniczących w badaniu nauczycieli, ale jednak to niedająca się zignorować grupa nauczycieli, z którą można wiązać nadzieję na szersze społeczne uznanie wykształcenia jako wartości samej w sobie. Oznacza to też szansę na organizowanie edukacji pod kątem zbiegania się jej z autonomicznym rozwojem indywidualnym każdego ucznia.
Druga hipoteza dotyczy szczególnej degradacji etycznej pozycji autora wytworów intelektualnych w szkole do pragmatycznej roli uczestnika w obrocie wytworami intelektualnymi. Jak można to zauważyć w Tabeli 2, pragmatyczne wartościowanie autorstwa odnotowano w 72 przypadkach, a etyczne w 18 wypadkach. Olbrzymia większość biorących udział w badaniu nauczycieli (80\%) argumentuje pragmatycznie za ochroną praw autorskich jako praw własności, odwołując się przede wszystkim do konieczności przestrzegania odpowiednich norm, zasad, regulaminów. Mniejszość w grupie badanych nauczycieli (20\%) skupia się przede wszystkim na etycznych aspektach autorstwa wytworów edukacyjnych w szkole, w których szacunek dla osoby autora rodzi odpowiedzialność za jego wytwory, a podejmując ją, daje on świadectwo zdolności do rozwoju własnej aktywności intelektualnej i brania za nią odpowiedzialności.

W trzeciej hipotezie mowa o związku między wartościowaniem edukacji a ujęciem autorstwa wytworów intelektualnych w szkole. Jak to podano przy Tabeli 2, testy statystyczne Chi2 i T-Studenta dają podstawę do przyjęcia tej zależności na podstawie rozkładu danych widocznych w tej tabeli. Ma on zachodzić w ten sposób, że autonomia edukacji idzie w parze $\mathrm{z}$ etycznym ujęciem autorstwa, a heteronomia z pragmatycznym ujęciem. Istotnie, jak można to zauważyć w Tabeli 2, w 69 przypadkach należy odnotować drugą parę - heteronomię edukacji z pragmatycznym ujęciem autorstwa, a w 13 przypadkach mamy pierwszą parę, a więc autonomię $z$ etycznym ujęciem autorstwa wy-

Tabela 2. Autorstwo wytworów intelektualnych w szkole w zależności od wartości edukacji.

\begin{tabular}{|l|r|r|r|}
\hline \multirow{2}{*}{ Wartość autorstwa } & \multicolumn{3}{|c|}{ Wartość edukacji } \\
\cline { 2 - 4 } & Autonomiczna & Heteronomiczna & Razem \\
\hline Etyczna & $13(72 \%)$ & $5(28 \%)$ & $18(100 \%)$ \\
& $(81 \%)$ & $(7 \%)$ & $(20 \%)$ \\
\hline Pragmatyczna & $3(4 \%)$ & $69(96 \%)$ & $72(100 \%)$ \\
& $(19 \%)$ & $(93 \%)$ & $(80 \%)$ \\
\hline Razem & $16(17 \%)$ & $74(83 \%)$ & $(100 \%)$ \\
& $(100 \%)$ & $(100 \%)$ & $(100 \%)$ \\
\hline
\end{tabular}

Uwaga: $N=180, d f=1$, Chi2 $=132,71, p<.05 ;$ T-studenta $p=.006$ 
tworów intelektualnych w szkole. Stanowią one łącznie 91\% przypadków, które przemawiają za przyjęciem hipotezy trzeciej. Zdecydowanie należy stwierdzić, że instrumentalne wartościowanie edukacji jako środka do innych niż edukacyjne celów komponuje się w badanej grupie nauczycieli z pragmatycznym ujęciem autorstwa wytworów intelektualnych. Autorstwo w tym ujęciu schodzi na dalszy plan, a najważniejsza okazuje się wymienna wartość wytworów w transakcjach społecznych.

Wobec jednoznacznego stwierdzenia, że zebrane dane empiryczne układają się zgodnie $\mathrm{z}$ tym, co wynika $\mathrm{z}$ hipotez, można $\mathrm{z}$ dużym prawdopodobieństwem przyjąć hipotezy za twierdzenia adekwatne do rzeczywistości, o której w nich mowa. Heteronomia edukacji powiązana z pragmatyczną wartością wytworów edukacyjnych dominują w myśleniu nauczycieli o wartości edukacji i o położeniu oraz odpowiedzialności ucznia w szkole.

\section{WNIOSKI DLA ZARZĄDZANIA ZMIANĄ W KIERUNKU AUTONOMII EDUKACJI W SZKOLE}

Wydaje się oczywiste, że zarządzanie edukacją w szkole nie może nie być odpowiednie do materii edukacyjnej, która stanowi przedmiot tego zarządzania. Materią współczesną edukacji jest przede wszystkim wybrany przez dorosłych przekaz kulturowy do młodych z zasobów ludzkiej cywilizacji pod kątem panującego ładu i porządku społeczno-kulturowego. Głównymi słabościami tej edukacji jest skupienie na przeszłości, w której powstał przekazywany dorobek cywilizacyjny oraz podporządkowanie teraźniejszości i przyszłości ładowi kulturowemu i porządkowi społecznemu przeszłości, jaka ten dorobek zrodziła.

Skupienie na przeszłości odwraca uwagę i zaangażowanie od realnego, bieżącego stanu rzeczy w świecie. Podporządkowanie panującemu ładowi i porządkowi ogranicza odpowiedzialność indywidualnych osób do posłuszeństwa i pilnowania, aby inni też byli posłuszni wobec konserwowanych tym sposobem panujących systemów normatywnych. Tym zainte- resowana jest obecna struktura władzy i z tego powodu podporządkowuje sobie ona edukację w szkołach.

Zmiana w kierunku autonomii wymaga skupienia uwagi uczniów i nauczycieli w szkole na aktualnym, bieżącym i realnym stanie rzeczy w świecie, który jest źródłem wyzwań, problemów i zadań dla ludzi starających się ułożyć sobie w nim indywidualne i społeczne życie godne człowieka.

Całkowita emancypacja edukacji we współczesnym świecie nie jest realną możliwością, lecz próby poszerzania jej obszaru nie są skazane na niepowodzenie, a $\mathrm{z}$ pewnością $\mathrm{s}$ ą warte $\mathrm{zachodu}$. Wcale przy tym nie muszą prezentować się jako bunt i destrukcja istniejącego ładu i porządku. Racjonalne wyważenie tego, co jest możliwe do zmiany, a co obecnie nie warto naruszać, może się opierać na myśleniu zaangażowanym po stronie autonomicznej wartości edukacji. W ten sposób można utrzymać kierunek działania, a mniejsze czy większe kroki na tej drodze podyktuje właśnie rozumne rozstrzygnięcie, co jest możliwe i co warto zrobić, a co jest nierealne i szkoda o to zachodu w obecnych okolicznościach.

Utrzymanie w działaniu reformatorskim kierunku na autonomię edukacji wymaga nieustającego wysiłku umysłowego skupionego na interpretacji i konkretyzacji tego ideału w konkretnych warunkach tu i teraz. Użyteczne w tym celu mogą okazać się wskaźniki użyte w badaniu do identyfikacji tego ukierunkowania. Także wskaźniki szacunku dla autorstwa wytworów edukacyjnych warte są uwagi w tym celu, są one bowiem związane - jak się okazuje - $\mathrm{z}$ ukierunkowaniem na autonomiczną wartość edukacji. Sformułowanie parami wskaźników obu rodzajów dobrze może dobrze posłużyć tej konkretyzacji. W tym zastosowaniu mogą one pokazywać, od czego staramy się odejść, a w stronę czego idziemy.

Trzecia para wskaźników (por. Tabela 1) powie nam np. o odchodzeniu od widzenia zadania nauczyciela w przekazie wiedzy, umiejętności i postaw oraz w ocenie stopnia przyswojenia tego przekazu przez ucznia, a zarazem mówi ona o przechodzeniu do podejmowania przez 
nauczyciela zadania wspomagania uczniów w stawianiu sobie celów na drodze do opanowania kompetencji poznawczych, aksjologicznych, społecznych, interpersonalnych oraz kompetencji radzenia sobie z samym sobą. Tak samo wskaźniki podejścia do autorstwa wytworów edukacyjnych są użyteczne w działaniu na rzecz poszerzania obszarów autonomii edukacji w szkole. Na przykład trzecia para na tej dymensji (por. Tabela 1) sugeruje odchodzenie od przekazania do obiegu społecznego w szkole wytworów edukacyjnych ucznia, w tym ich oceny bez potrzeby pytania go o zgodę, a pokazuje kierunek na uszanowanie suwerennej decyzji ucznia o tym, co, komu, kiedy i w jakim celu udostępni on ze swoich wytworów w szkole. I tak dalej podobnie w wypadku pozostałych par wskaźników można zobaczyć, jak one mogą się przydać do opracowania konkretnych sposobów odchodzenia od heteronomicznych presji
W stronę odpowiedzialnego cieszenia się wolnością edukacji w szkole.

Takie stopniowe przekształcenie edukacji w szkole nie może się odbywać bez równoległego, a co najmniej podążającego za nim przekształcenia organizacji pracy szkoły i sposobu zarządzania funkcjonowaniem uczniów, nauczycieli, rodziców, ale także zmian relacji z władzą oświatową oraz nawiązania kontaktu $\mathrm{z}$ bezpośrednią lokalną społecznością. Tym zagadnieniom poświęcona została seria rozpraw doktorskich powstałych na seminarium profesora Adama Niemczyńskiego (Dorczak, 2004; Kołodziejczyk, 2004; Solecka, 2005; Lazar-Siekierka, 2012; Dudek, 2015; Serafin, 2017). Tutaj chodzi o to, aby podkreślić, że tego rodzaju przekształcenia wzmacniają szanse autonomii edukacji i zwiększają znaczenie autorstwa wytworów edukacyjnych, a redukują rację bytu oszustwa edukacyjnego w szkole.

\section{BIBLIOGRAFIA}

Bauman Z. (1994), Dwa szkice o moralności ponowoczesnej. Warszawa: Instytut Kultury.

Blum L. (1994), Moral Perception and Particularity. Cambridge: Cambridge University Press.

Bourdieu P., Passeron J.C. (2006), Reprodukcja. Elementy teorii systemu nauczania. Warszawa: Wydawnictwo Naukowe PWN.

Dorczak R. (2004), System normatywny instytucji edukacyjnej - badania porównawcze w dekadzie lat 1990 2000. Kraków: Wydział Zarządzania i Komunikacji Społecznej Uniwersytetu Jagiellońskiego. Rozprawa doktorska.

Dudek K. (2015), Rola etycznych wartości w zarządzaniu szkołą. Kraków: Wydział Zarządzania i Komunikacji Społecznej Uniwersytetu Jagiellońskiego. Rozprawa doktorska.

Ingarden R. (1972), O odpowiedzialności i jej podstawach ontycznych. W: R. Ingarden, Ksiązeczka o człowieku, 71-156. Kraków: Wydawnictwo Literackie.

Ingarden R. (1976), O poznawaniu dzieła literackiego. Warszawa: Państwowe Wydawnictwo Naukowe.

Kohlberg L., Mayer R. (1993), Rozwój jako cel wychowania. W: Z. Kwieciński, L. Witkowski (red.), Spory o edukację, 49-95. Warszawa: Instytut Badań Edukacyjnych.

Kołodziejczyk K. (2004), Znaczenie konceptualizacji ideału wychowania dla zarządzania oświata. Kraków: Wydział Zarządzania i Komunikacji Społecznej Uniwersytetu Jagiellońskiego. Rozprawa doktorska.

Lazar-Siekierka M.(2012), Zarządzanie transformacją szkoły dla twórczości edukacyjnej. Kraków: Wydział Zarządzania i Komunikacji Społecznej Uniwersytetu Jagiellońskiego. Rozprawa doktorska.

Łuczyński J. (2009), Zarządzanie edukacyjne jako warunek rozwoju indywidualnego. W: M. Kielar-Turska (red.), Studia nad rozwojem i wychowaniem. W osiemdziesiata rocznice powstania Zakladu Psychologii Rozwojowej i Wychowawczej na Uniwersytecie Jagiellońskim. Kraków: Wydawnictwo Uniwersytetu Jagiellońskiego.

Łuczyński J. (2011), Zarzadzanie edukacyjne a wychowanie uczniów w szkole. Kraków: Wydawnictwo Uniwersytetu Jagiellońskiego.

Macnamara J. (1990), Ideals and Psychology. Canadian Psychology, 31, 14-25. 
Niemczyński A. (1988), Procesy rozwojowe człowieka w pełnym cyklu życia indywidualnego. W: M. Tyszkowa (red.), Rozwój psychiczny człowieka w ciagu życia. Zagadnienia teoretyczne i metodologiczne, 223-233. Warszawa: Państwowe Wydawnictwo Naukowe.

Niemczyński A. (1994), O autonomii rozwoju [Zarys problematyki]. Kwartalnik Polskiej Psychologii Rozwojowej, 2(1), 3-11.

Niemczyński A. (2000), Szanse na powrót ideałów do psychologii rozwoju człowieka. Psychologia Rozwojowa, 5(1-2), 11-25.

Niemczyński A. (2003-2007), Seminarium z zarządzania w edukacji. Instytut Spraw Publicznych Uniwersytetu Jagiellońskiego.

Niemczyński A. (2007), Inner Regulatory Device for Adult Development. Polish Psychological Bulletin, 38(3), 133-139.

Niemczyński A. (2011), Praktyczne implikacje wiedzy o rozwoju społeczno-moralnym. W: J. Trempała (red.), Psychologia rozwoju człowieka, 364-375. Warszawa: Wydawnictwo Naukowe PWN.

Niemczyński A. (2011-2015), Elektroniczne seminarium z zarządzania w edukacji. Instytut Spraw Publicznych Uniwersytetu Jagiellońskiego.

Niemczyński A. (2014), Dylematy wartości na różnych polach przedsiębiorczości. W: Z. Ratajczak (red.), Przedsiębiorczość, czyli pochwała kryzysu, 103-111. Katowice: Górnośląska Wyższa Szkoła Handlowa.

Niemczyński A. (2016a), Rozwój i wychowanie wedtug wartości. Referat przedstawiony na XXV Jubileuszowej Ogólnopolskiej Konferencji Psychologii Rozwojowej. Maszynopis przed drukiem.

Niemczyński A. (2016b), Dialektyka interesowności i altruizmu edukacji i zarzadzania edukacja. Referat przedstawiony na konferencji „Psychologia w biznesie”. Katowice: V Ogólnopolska Konferencja Naukowa Katedry Psychologii GWSH.

Niemczyński A. (2017), Autonomy of Human Mind and Personality Development. Polish Psychological Bulletin, 48(1), 7-19.

Piaget J. (1966a), O rozwoju ocen moralnych dziecka. Warszawa: Państwowe Wydawnictwo Naukowe.

Piaget J. (1966b), Studia z psychologii dziecka. Warszawa: Państwowe Wydawnictwo Naukowe.

Piaget J. (1977a), Dokad zmierza edukacja. Warszawa: Państwowe Wydawnictwo Naukowe.

Piaget J. (1977b), Psychologia i epistemologia. Warszawa: Państwowe Wydawnictwo Naukowe.

Przetacznikowa M. (1973), Podstawy rozwoju psychicznego dzieci i młodzieży. Warszawa: Państwowy Zakład Wydawnictw Szkolnych.

Serafin J. (2017), Technologie informacyjno-komunikacyjne $w$ zarzadzaniu edukacja $w$ szkole podstawowej i ponadpodstawowej. Kraków: Wydział Zarządzania i Komunikacji Społecznej Uniwersytetu Jagiellońskiego. Rozprawa doktorska.

Solecka K. (2005), Rola ideatów edukacyjnych w zarządzaniu oświatą. Kraków: Wydział Zarządzania i Komunikacji Społecznej Uniwersytetu Jagiellońskiego. Rozprawa doktorska.

Szuman S. (1955), Rola działania w rozwoju umystowym małego dziecka. Wrocław: Ossolineum.

Szuman S. (1959), O czynnikach kształtujących psychikę dziecka w wieku przedszkolnym. Kwartalnik Pedagogiczny, 4, 143-158.

Szuman S. (2014), Osobowość i charakter. Warszawa: Wydawnictwo Naukowe PWN.

Tischner J. (1982), Myślenie wedtug wartości. Kraków: Wydawnictwo Znak.

Wygotski L.S. (1971), Wybrane prace psychologiczne. Warszawa: Państwowe Wydawnictwo Naukowe. 